\title{
Phytoprotection
}

\section{Evaluation of alfalfa resistance to the pea aphid, Acyrtosiphon pisum [Homoptera : Aphididae] - Methodological aspects to improve a standardized speedling test Évaluation de la résistance de la luzerne au puceron du pois, Acyrtosiphon pisum [Homoptera : Aphididae] - Améliorations méthodologiques d'un test " plantule " standardisé}

\author{
C. Girousse, R. Bournoville et I. Badenhausser
}

\section{Volume 79, numéro 3, 1998}

URI : https://id.erudit.org/iderudit/706142ar

DOI : https://doi.org/10.7202/706142ar

\section{Aller au sommaire du numéro}

Éditeur(s)

Société de protection des plantes du Québec (SPPQ)l

ISSN

0031-9511 (imprimé)

1710-1603 (numérique)

Découvrir la revue

Citer cet article

Girousse, C., Bournoville, R. \& Badenhausser, I. (1998). Evaluation of alfalfa resistance to the pea aphid, Acyrtosiphon pisum [Homoptera : Aphididae] Methodological aspects to improve a standardized speedling test. Phytoprotection, 79(3), 139-148. https://doi.org/10.7202/706142ar

\section{Résumé de l'article}

Cette étude concerne des éléments de standardisation pour mettre en oeuvre un test d'évaluation de la résistance variétale de la luzerne (Medicago sativa) au puceron du pois (Acyrthosiphon pisum). Réalisé en conditions contrôlées, il évalue la résistance de plantules à l'infestation aphidienne. Pour réaliser cette dernière, il est nécessaire de produire les pucerons sur des plantes de luzerne plutôt que sur des plantes de féverole, leur action sur la luzerne étant alors moindre. La disposition d'un seul cultivar (condition de "non choix») donne les mêmes résultats que la disposition dans la même unité de plusieurs variétés (conditions de choix) et est plus facile à gérer. L'unité élémentaire, constituée de 54 plantules, est infestée avec $360 \mathrm{mg}$ de pucerons lorsque les cotylédons s'ouvrent, ce que l'on renouvelle après 5 jours. Cette dose conduit à des résultats optimums par rapport à des infestations réalisées dans les mêmes conditions avec 180 ou $540 \mathrm{mg}$. L'infestation est arrêtée lorsque $60 \%$ des plantules d'un cultivar sensible dépérissent ou meurent. Dans ces conditions, nous avons calculé le nombre de répétitions nécessaires. Six unités élémentaires permettent alors d'apprécier une différence de mortalité entre cultivars de $20 \%$. 


\title{
Evaluation of alfalfa resistance to the pea aphid, Acyrthosiphon pisum [Homoptera: Aphididae] Methodological aspects to improve a standardized seedling test
}

\author{
Christine Girousse, René Bournoville and \\ Isabelle Badenhausser ${ }^{1}$
}

Received 1998-10-15; accepted 1999-03-15

PHYTOPROTECTION 79 : 139-148

This study proposes a guide for the design of experiments to test alfalfa (Medicago sativa) for resistance to pea aphid infestation (Acyrthosiphon pisum). This test was conducted in controlled conditions on alfalfa seedlings. For the infestation, aphid population maintained on alfalfa was found to be more efficient than an aphid population reared on broad bean. When comparing alfalfa cultivars, a non-choice test gave the same results as a choice test, that was more difficult to perform. When infesting a unit of 54 seedlings at the cotyledon stage on the $1^{\text {st }}$ and $5^{\text {th }}$ day of the experiment, $360 \mathrm{mg}$ compared with $180 \mathrm{mg}$ and $540 \mathrm{mg}$ aphids, led to the best compromise between levels of infestation and aphid stock culture availability. Infestation was stopped when more than $60 \%$ of susceptible cultivar seedlings were wilted or dead. Under these conditions, we calculated the number of replicates necessary to obtain a fixed level of difference. Six units per cultivar would distinguish between cultivars differing from $20 \%$ in their seedling mortality.

[Évaluation de la résistance de la luzerne au puceron du pois, Acyrthosiphon pisum [Homoptera : Aphididae] - Améliorations méthodologiques d'un test uplantule» standardisé]

Cette étude concerne des éléments de standardisation pour mettre en oeuvre un test d'évaluation de la résistance variétale de la luzerne ( $M e$ dicago sativa) au puceron du pois (Acyrthosiphon pisum). Réalisé en conditions contrôlées, il évalue la résistance de plantules à l'infestation aphidienne. Pour réaliser cette dernière, il est nécessaire de produire les pucerons sur des plantes de luzerne plutôt que sur des plantes de féverole, leur action sur la luzerne étant alors moindre. La disposition d'un seul cultivar (condition de "non choix») donne les mêmes résultats que la disposition dans la même unité de plusieurs variétés (conditions de choix) et est plus facile à gérer. L'unité élémentaire, constituée de 54 plantules, est infestée avec $360 \mathrm{mg}$ de pucerons lorsque les cotylédons s'ouvrent, ce que I'on renouvelle après 5 jours. Cette dose conduit à des résultats optimums par rapport à des infestations réalisées dans les mêmes conditions avec 180 ou $540 \mathrm{mg}$. L'infestation est arrêtée lorsque $60 \%$ des plantules d'un cultivar sensible

1. Laboratoire de Zoologie, Institut national de la Recherche agronomique, 86600 Lusignan, France 
dépérissent ou meurent. Dans ces conditions, nous avons calculé le nombre de répétitions nécessaires. Six unités élémentaires permettent alors d'apprécier une différence de mortalité entre cultivars de $20 \%$.

\section{INTRODUCTION}

The evaluation of plants for insect resistance may be based on plant damage or on insect responses to plants. Although pea aphid (PA) Acyrthosiphon pisum (Harris) [Homoptera: Aphididae] is one of the main pests of alfalfa (Medicago sativa L.) in Europe (Bournoville 1976), there are few European studies about methodologies for evaluating alfalfa resistance to PA whatever the underlying type of resistance, tolerance or antibiosis (Bournoville 1980; Bournoville and Comte 1977; Girousse and Bournoville 1994). In North America, various methods for the evaluation of alfalfa resistance to the PA have been carried out, mainly under greenhouse conditions (Hackerott et al., 1963; Kugler and Ratcliffe 1983; Nielson and Lehman 1977; Ortman et al. 1960), sometimes in growth chambers (Kugler and Ratcliffe 1983) or outside under screen cages (Carnahan et al. 1963; Smith and Peaden 1960). Studies about methods to test alfalfa resistance under field conditions have also been carried out in Australia because of the high level of aphid infestations in that country (Holtkamp and Clift 1993). The existence of several different evaluation procedures for resistance is surprising, as breeding programs need efficient, simple and accurate screening methods (Smith et al. 1994) which should be standardized (Sorensen et al. 1988).

The most recent standardization of a method to test alfalfa resistance to the $\mathrm{PA}$, at a seedling stage has been described by Berberet et al. (1991). Nevertheless, some methodological elements remained to be demonstrated. Our aim was then to clarify three of these elements, running three different experiments.

1 - Is it relevant to use PA reared on faba bean Vicia faba L. (instead of alfalfa which is more difficult to grow) in a test of resistance of alfalfa seedlings to PA ? (Experiment 1).

2 - Is it possible to use a non-choice test instead of a more complicated choice test when comparing alfalfa genotypes for resistance to PA ? (Experiment 2).

3 - What are the minimum aphid biomasses and number of insect releases necessary for detecting resistance of alfalfa seedlings? (Experiment 3). In fact, if infesting populations are too high, moderate levels of resistance may appear susceptible, whereas when insect populations are too low, the screening between resistant and susceptible cultivars may be unreliable (Smith et al. 1994).

Experiments were carried out on alfalfa cultivars with well-known degree of resistance in controlled conditions as the expression of alfalfa resistance to aphids could vary according to the temperature as reported for the pea aphid (Isaak et al. 1963, 1965), the spotted alfalfa aphid, Therioaphis maculata [Homoptera: Aphididae] Buckton (Schalk et al. 1969) and the blue alfalfa aphid, Acyrthosiphon kondoi [Homoptera: Aphididae] Shinji (Summers 1988).

\section{MATERIAL AND METHODS}

\section{Plants}

Alfalfa seeds were germinated on a wet filter paper in Petri dishes. After 3 to 4 $d$, when the cotyledons were opening and young roots were about $1 \mathrm{~cm}$ long, seedlings were planted in individual peat pots $(4 \mathrm{~cm} \times 4 \mathrm{~cm} \times 5 \mathrm{~cm}$, Jiffy-pots Reg.) containing a soil mixture (sand, compost, vegetal earth) which had been sieved and heated to destroy pathogens and other seeds. A tray consisting of 54 (six rows $x$ nine columns) peat-pots, thereafter called an unit, was put in a screened cage $(40 \mathrm{~cm} \times 35 \mathrm{~cm} \times 30 \mathrm{~cm})$ 
with a transparent opening. This allowed seedling growth and watering and aphid population growth. All the experiments were carried out in a growth chamber. The air temperature was maintained at $20^{\circ} \mathrm{C} \pm 2{ }^{\circ} \mathrm{C}$ with a photoperiod of $16: 8$ (L:D) and a relative humidity varying from $70 \%(\mathrm{~L})$ to $90 \%$ (D). Light intensity was $95 \mu \mathrm{mol} \mathrm{m} \mathrm{m}^{-2} \mathrm{~s}^{-1}$ at $75 \mathrm{~cm}$ from fluorescent tubes, i.e., above the seedlings.

Standard test for $\mathrm{PA}$ resistance (Berberet et al. 1991) refered to 'CUF 101' as resistant and 'Moapa 69' or 'Vernal' as susceptible cultivars (US origin). In these experiments, we used 'CUF 101' and a French cultivar 'Milfeuil' as a susceptible control.

\section{Insects}

Aphids were collected in a alfalfa field in the INRA experimental station in Lusignan (near Poitiers, France). This aphid population was reared either on faba bean (cv. Aguadulce), or on the susceptible alfalfa cultivar 'Milfeuil' in a growth chamber at $21^{\circ} \mathrm{C}$, photoperiod 16:8 (L:D) at $75 \% \mathrm{RH}$.

\section{Infestations and observations}

Plants were infested $1 \mathrm{~d}$ after transplanting into peat-pots with a mixed population of nymphs and adults of $A$. pisum by sprinkling aphids as evenly as possible over the seedlings. As aphid weight is well-correlated with aphid fecundity and therefore is a good marker for potential population dynamics, 20 randomly chosen wingless aphids of PA were weighed using a $10^{-5} \mathrm{~g}$ microbalance, just before the infestations. It allowed us to check whether all the experiments were conducted with comparable presumed aphid performances.

In testing seedling resistance to $P A$, our observations concerned only alfalfa seedlings because our design did not allow for recording aphid performance, such as aphid mortality or fecundity. Each seedling was rated according to a 3-class system : dead, wilted or healthy. The different stages of development of the healthy seedlings were described as their number of leaves : $C$ : cotyledons; $\mathrm{LO}$ : the first unifoliate leaf; $\mathrm{Li}$ : i trifoliate leaves. Throughout the experiments, the infestations were stopped with a spray of deltamethrin ( $37.5 \mathrm{mg} \mathrm{L}^{-1}$ ) when more than $60 \%$ of 'Milfeuil' seedlings were dead or wilted and all the observations were made immediately after spraying. In all experiments, treatments were compared using the proportions of dead plus wilted seedlings per unit. The proportions of seedlings from the different stages of development were used for the interpretation of the results.

\section{Experimental design}

Three experiments were carried out consecutively to define the standards of the test. The results of one experiment were considered when designing into the following one. An uninfested control was added in each experiment to verify that the growth of the seedlings was optimal.

\section{Influence of the host plant for aphid production (Exp. 1)}

Two treatments were compared for each cultivar ('Milfeuil' and 'CUF 101') each using one unit of 54 seedlings : infestation was realized with our aphid strain reared either on faba bean or on alfalfa for several mo. Each seedling was infested using two adults of $A$. pisum (Berberet et al. 1991).

Choice or non choice test (Exp. 2) Two treatments were compared.

(1) 'CUF 101' and 'Milfeuil' planted in alternate rows and infested (two units of 54 seedlings) ;

(2) 'CUF 101' or 'Milfeuil' planted each in separated units and infested (one unit per cultivar).

Two adults of $A$. pisum (reared on alfalfa) per seedling were used for the first infestation. A second infestation was carried out $7 \mathrm{~d}$ later using one $A$. pisum adult per seedling.

Aphid biomass (Exp. 3)

As aphids are easier to weigh than to isolate and to count, we tried to determine an infesting biomass of aphids in place of a number of adults as previously used. In terms of biomass, an infestation with $180 \mathrm{mg}$ per unit was equivalent to an infestation carried out 
with two adult aphids per plant (as the mean weight of an adult is $1.7 \mathrm{mg}$ ). Then, three treatments were compared each using two units planted with 'Milfeuil' and two units planted with 'CUF 101 ' in a non-choice design. The initial biomass of aphids added to the treatments was as follows : 1) 180 mg aphids; 2) $360 \mathrm{mg}$ aphids; 3) $540 \mathrm{mg}$ aphids reared on alfalfa. A second infestation with the same biomass was realized 4 d later.

\section{Statistical analysis}

\section{Estimation of the proportions (p) and their standard errors (SE(p))}

In the case where there was one unit of $m$ seedlings per treatment, $p$ and $S E(p)$ were calculated as follows:

$$
p=\frac{y}{m}
$$

and

$$
S E(p)=\sqrt{p(1-p) / m}
$$

where $y$ is the number of seedlings that fall into a defined class (for example dead seedlings).

In the case where there were $n$ units of $m_{i}$ seedllings per treatment, $p$ and $S E(p)$ were calculated according to Cochran (1977) :

$$
p=\frac{\sum_{i=1}^{n} y_{i}}{\sum_{i=1}^{n} m_{i}}
$$

and

\section{Comparisons of the proportions of a defined class}

The comparison of two proportions was conducted using the exact test (Dagnelie, 1986) based on the probability term $(\mathrm{Pr})$ for the hypergeometric distribution. Under the hypothesis of the equality of proportions, Pr gives the probability to encounter a more abnormal frequency distribution than observed.

\section{RESULTS}

\section{Exp. 1 - Influence of the host plant for aphid reproduction}

Whatever the cultivar, the effect of the aphids reared on alfalfa was significantly different from that of the aphids reared on faba bean ( $\operatorname{Pr}=0.014$ for 'CUF 101' and $\operatorname{Pr}=10^{-11}$ for 'Milfeuil'). When infestation was carried out with aphids reared on faba bean, the proportion of wilted plus dead seedlings was nil for 'CUF 101 ' and 0.02 for 'Milfeuil' (Table 1). When infestation was carried out with aphids reared on alfalfa, this proportion was higher and consistent with that of previous tests where the level of susceptibility was about $30 \%$ of dead seedlings for 'CUF 101' (Berberet et al. 1991), and 70\% for 'Milfeuil'.

Although there was no seedling mortality when aphids were reared on faba bean, there was a delay in phenology when compared with the uninfested control where almost all the seedlings developed one trifoliate leaf (Table 1). This delay was more important when seedlings were infested with aphids reared on alfalfa. The phenology revealed differences between 'CUF 101' and 'Milfeuil', with 'CUF 101' seedlings being more developed than those of 'Milfeuil'. The conclusion is that, whatever the alfalfa cultivar (susceptible or resistant), aphid impact on alfalfa seedlings depends on the host plant used for aphid reproduction; in the following experiments we used aphids reared on alfalfa. 
Table 1. Influence of the host-plant species for aphid reproduction ( $A=$ alfalfa ; $B=$ faba bean) on aphid damaging effect. Proportions $p$ and standard error $S E(p)$ in parenthesis of healthy, wilted and dead seedlings

\begin{tabular}{|c|c|c|c|c|c|}
\hline \multirow[b]{2}{*}{ Seedling class } & \multicolumn{2}{|c|}{$\begin{array}{l}\text { 'CUF 101' infested with aphids } \\
\text { from }\end{array}$} & \multicolumn{2}{|c|}{$\begin{array}{l}\text { 'Milfeuil' infested with aphids } \\
\text { from }\end{array}$} & \multirow[b]{2}{*}{$\begin{array}{l}\text { Uninfested } \\
\text { control }\end{array}$} \\
\hline & $A$ & B & $A$ & B & \\
\hline Healthya & $0.88(0.05)$ & $1.00(0.00)$ & $0.35(0.07)$ & $0.98(0.02)$ & $1.00(0.00)$ \\
\hline C & $0.10(0.04)$ & $0.06(0.03)$ & $0.13(0.05)$ & $0.14(0.05)$ & $0.02(0.02)$ \\
\hline LO & $0.72(0.07)$ & $0.25(0.06)$ & $0.22(0.06)$ & $0.27(0.06)$ & $0.06(0.03)$ \\
\hline L1 & $0.06(0.03)$ & $0.69(0.07)$ & $0.00(0.00)$ & $0.57(0.07)$ & $0.92(0.04)$ \\
\hline Wilted & $0.12(0.05)$ & $0.00(0.00)$ & $0.03(0.02)$ & $0.02(0.02)$ & $0.00(0.00)$ \\
\hline Dead & $0.00(0.00)$ & $0.00(0.00)$ & $0.62(0.07)$ & $0.00(0.00)$ & $0.00(0.00)$ \\
\hline Wilted + dead & $0.12(0.05)$ & $0.00(0.00)$ & $0.65(0.07)$ & $0.02(0.02)$ & $0.00(0.00)$ \\
\hline
\end{tabular}

a For healthy seedlings, the proportions of the seedlings at different developmental stages are detailed : C: cotyledons; L0: unifoliate leaves; L1: first trifoliate leaves.

Table 2. Comparison of choice / non-choice test. Proportions $p$ and standard error $S E(p)$ in parenthesis of healthy, wilted and dead seedlings

\begin{tabular}{|c|c|c|c|c|c|}
\hline \multirow[b]{2}{*}{ Seedling class } & \multicolumn{2}{|c|}{ 'CUF 101' } & \multicolumn{2}{|c|}{ 'Milfeuil' } & \multirow[b]{2}{*}{$\begin{array}{l}\text { Uninfestec } \\
\text { control }\end{array}$} \\
\hline & Choice & Non-choice & Choice & Non-choice & \\
\hline Healthy ${ }^{a}$ & $0.84(0.05)$ & $0.80(0.06)$ & $0.17(0.05)$ & $0.19(0.05)$ & $0.92(0.04)$ \\
\hline C & $0.00(0.00)$ & $0.06(0.03)$ & $0.00(0.00)$ & $0.00(0.00)$ & $0.00(0.00)$ \\
\hline LO & $0.09(0.04)$ & $0.14(0.05)$ & $0.13(0.05)$ & $0.17(0.05)$ & $0.00(0.00)$ \\
\hline L1 & $0.08(0.04)$ & $0.04(0.03)$ & $0.02(0.02)$ & $0.02(0.02)$ & $0.02(0.02)$ \\
\hline L2 & $0.15(0.05)$ & $0.18(0.05)$ & $0.02(0.02)$ & $0.00(0.00)$ & $0.00(0.00)$ \\
\hline L3 & $0.30(0.06)$ & $0.28(0.06)$ & $0.00(0.00)$ & $0.00(0.00)$ & $0.61(0.07)$ \\
\hline L4 & $0.22(0.06)$ & $0.10(0.04)$ & $0.00(0.00)$ & $0.00(0.00)$ & $0.29(0.06)$ \\
\hline Wilted & $0.09(0.04)$ & $0.14(0.05)$ & $0.46(0.07)$ & $0.62(0.07)$ & $0.04(0.03)$ \\
\hline Dead & $0.07(0.04)$ & $0.06(0.03)$ & $0.37(0.07)$ & $0.19(0.05)$ & $0.04(0.03)$ \\
\hline Wilted + dead & $0.16(0.05)$ & $0.20(0.06)$ & $0.83(0.05)$ & $0.81(0.05)$ & $0.08(0.04)$ \\
\hline
\end{tabular}

a For healthy seedlings, the proportions of the seedlings at different developmental stages are detailed : C: cotyledons; LO: unifoliate leaves; Li: ith trifoliate leaves.

Exp. 2 - Choice or non choice test As there was no difference in the proportions of wilted and dead seedlings between the two replicates of treatment 1 (choice test) ( $\mathrm{Pr}=0.52$ for 'CUF 101' and $\operatorname{Pr}=0.195$ for 'Milfeuil'), data were pooled. The proportion of wilted plus dead seedlings are reported for both cultivars and tests (Table 2). There was no difference between the two kinds of test whatever the cultivar $(\operatorname{Pr}=0.463$ for 'CUF 101 ' and $\operatorname{Pr}=0.693$ for 'Milfeuil'). The same difference as in experiment 1 was observed in the susceptibility of the two cultivars, even if the proportion of wilted plus dead seedlings was higher because of longer duration of the infestation : about $20 \%$ for 'CUF 101 ' and about $80 \%$ for 'Milfeuil' in a nonchoice test.

The developmental stages of surviving seedlings for both cultivars and devices are reported in Table 2. Generally, the seedlings were more developed in this experiment than in the previous one because of the longer duration of the experiment (12 more d). The difference in susceptibility between 'CUF 101' and 'Milfeuil' was also 
expressed in the developmental stages of surviving seedlings in a non-choice test : more than $56 \%$ of 'CUF 101' seedlings developed more than one trifoliate leaf, whereas no seedling of 'Milfeuil' had more than one trifoliate leaf. Apart from this, $90 \%$ of the uninfested control seedlings had more than two trifoliate leaves. In consequence, as a non choice device is easier to set up than a choice device, a non choice test was prefered.

\section{Exp. 3 - Aphid biomass}

As there was no difference for each cultivar in the proportions of wilted and dead seedlings between the two replicates of each biomass of aphids ( $\operatorname{Pr}>0.5$ whatever the biomass and the cultivar), data were pooled. Significant differences between the three biomasses were detected for each cultivar : $\operatorname{Pr}=3.5 \quad 10^{-10}$ for 'CUF 101' and $\mathrm{Pr}=7 \quad 10^{-20}$ for 'Milfeuil'. The infestations using the lowest biomass of aphids (180 mg) were not sufficient to induce a satisfying level of wilting and mortality of seedlings (Table 3) and to detect differences between the resistant and sensible cultivars ; we were unsuccessfull in reaching $60 \%$ of dead and wilted seedlings for 'Milfeuil'. The biomasses of $360 \mathrm{mg}$ and $540 \mathrm{mg}$ were equivalent whatever the cultivar. They induced 26 to $28 \%$ of wilted plus dead seedlings for 'CUF 101' and 59 to $66 \%$ for 'Milfeuil'. Such proportions allow the distinction between resistant and susceptible cultivars. These results led us to sprinkle aphids twice over seedlings in an experiment, with 4 or $5 \mathrm{~d}$ interval between sprinklings and to use biomasses of at least $360 \mathrm{mg}$ per unit of 54 .

\section{DISCUSSION}

\section{Standardization of seedling test of alfalfa resistance to the pea aphid}

Exp. 1. In the resistance tests described in the literature, the broad bean is often used because of its convenience to be planted and maintained in controlled conditions in order to breed large amounts of PA. For example, Ellsbury and Nielson (1981) reported that faba bean is a more favourable host plant for the pea aphid than alfalfa, but these authors used pea aphid colonies maintained on faba bean in order to compare a range of host plants and not cultivars of the same host plant. In our study, the comparison of the effect of aphids reared either on faba bean or on alfalfa revealed no difference in response to aphid infestation between susceptible ('Milfeuil') and resistant ('CUF 101') cultivars when aphids were reared on faba bean. It is likely due to the fact that aphids reared on faba bean were not conditioned to their new host (alfalfa) and resulting in a higher mortality of these aphids. These results are in accordance with those mentioned by Frazer (1972) collecting PA from four species (broom, broad bean, white clover and alfalfa). He noticed that broad bean was the only plant which allows the multiplication of the different strains, but the pea aphid reared on bean strains did not succeed on alfalfa 'Ladak'. The problem of preconditioning has also been emphasized by Schotzko and Smith (1991), who reported that the fecundity of the Russian wheat aphid,

Table 3. Estimations of proportions $p$ and their standard errors $S E(p)$ of dead plus wilted seedlings after infestations with different aphid biomasses

\begin{tabular}{|c|c|c|c|c|c|c|}
\hline & \multicolumn{3}{|c|}{$\begin{array}{c}\text { 'CUF 101' } \\
\text { Biomass of aphids by infestation } \\
\left(\mathrm{mg} \mathrm{unit}^{-1}\right)\end{array}$} & \multicolumn{3}{|c|}{$\begin{array}{c}\text { 'Milfeuil' } \\
\text { Biomass of aphids by infestation } \\
\left(\mathrm{mg} \mathrm{unit}^{-1}\right)\end{array}$} \\
\hline & 180 & 360 & 540 & 180 & 360 & 540 \\
\hline$p$ & 0.01 & 0.26 & 0.28 & 0.10 & 0.66 & 0.59 \\
\hline$S E(p)$ & 0.01 & 0.00 & 0.06 & 0.04 & 0.03 & 0.02 \\
\hline
\end{tabular}


Diuraphis noxia [Homoptera : Aphididae] (Mordvilko), is influenced by the preconditioning effect of wheat 'Stephens', when comparing this cultivar with oat 'Boarder'. To avoid the delay of the aphid effect on alfalfa seedlings during a resistance test, we suggest that PA should be reared on a susceptible cultivar of alfalfa. In our study, we chose to rear aphids on 'Milfeuil'.

Exp. 2. The seedling tests of resistance of alfalfa to $A$. pisum, $T$. maculata and $A$. kondoï are usually carried on under free-choice conditions, either in the initial tests in the USA (Ortman et al. 1960), or in the more recent tests in Australia (Ridland and Berg 1981). This gives the advantage of testing antixenosis and tolerance components of resistance. Under agronomic conditions, antixenosis is linked to alatae choice as reported by Holtkamp and Clift (1993). Under controlled conditions, the selective production of alatae in large amounts is rather complicated, or even impossible. Our mass inoculum of aphids included mainly apterae. Moreover, we proved the homogeneity of the response of the cultivars tested in choice or non-choice experiments. Consequently, we express the view that the non-choice test is adapted to our aim. It prevents any mixing of the seedlings owing to the separation of the different batches.

Exp. 3. The determination of the level of infestation is of primary importance for the success of the seedling test. Formerly, it has been described as "massive infestation" by Ortman et al. (1960), sprinkling additional aphids in order to maintain population as high as possible. Berberet et al. (1991) noted that the infestation procedure needs a minimum of two aphids per seedling and additional supplies if necessary. Other publications refered to the volume of aphids by reference to the unit of infestation (Hackerott et al. 1963; Nielson and Lehman 1977; Ridland and Berg 1981). The crucial point is to find a good compromise between an easy mass production of aphids and infestation levels inducing a suitable rate of the mortality in the susceptible cultivar control. Our results demonstrated that a low level of infestation (180 mg per unit) was not sufficient to induce a high mortality of 'Milfeuil' seedlings; on the contrary, the biomasses of $360 \mathrm{mg}$ and $540 \mathrm{mg}$ per unit were equivalent in terms of wilted plus dead seedlings. In our experimental conditions, $360 \mathrm{mg}$ per unit seemed to be a good compromise between aphid mass production and a good level of mortality in 'Milfeuil' seedlings (about $60 \%$ ). But this aphid biomass has to be adjusted to fit two other parameters : the phenological stage of seedlings and the size of experimental unit. The older the seedlings are when infested, the larger the aphid biomass has to be in order to induce a high mortality in the susceptible control. Then, to limit the amount of aphids, it seems that the plants need to be infested as early as possible, that is when the cotyledons are just opened. With regard to the size of experimental unit, with the same number of plants, a larger unit needs greater amounts of infesting aphids than a smaller one ; actually, in a large unit, aphids tend to wander. To prevent this aphid behaviour, it seems to be more convenient to use small experimental units, with equal number of plants. Lastly, it is important to make sure that the quality of infestation remains the same in all experiments ; a way to control infestation quality is to weigh wingless adults. For instance, in our conditions, if average weight is less than $1.5 \mathrm{mg}$ in our conditions, it would be better to cancel the test. Otherwise this could lead to a misinterpretation of the results, concluding the resistance of a cr instead of a lack of aphid effect.

\section{Repeatability of the test and number of replicates for treatment comparison}

The accuracy of the US seedling test is not reported in literature. It would be partly due to the difficulty of controlling the variability either of aphids, environments or plants that are many causes of variation. The test previously described was conducted for $3 \mathrm{yr}$ and it is interesting to take advantage of data collected during these independent tests for evaluating the repeatability of the test. We considered the results obtained for 
the same line 'Milfeuil' during three independent tests (1993, 1994, 1995) using five (yr 1993) or six units (yr 1994 and 1995). The conditions of infestations were those described above; the end of infestation occurred when more than $60 \%$ of the 'Milfeuil' seedlings were wilted or dead. The estimation of the proportions of wilted plus dead seedlings at the end of infestation for each of the three tests are reported on Table 4. There was no difference between the proportions obtained independently in the conditions of our growth chamber. Therefore, trying to control as many as possible of these parameters leads to results that clearly prove the homogeneity of responses of a seedling test conducted in growth chamber on alfalfa.

Using this test, significant differences between cultivars could be difficult to detect if the resistance levels of the cultivars are too close. It depends on the number of plants and/or units that are tested but the cost of sampling could then become high to obtain a small gain in precision. We can use the results of the same three independent tests described above and the variability of the proportions for the establishment of the number of replicates necessary for the comparison of two percentages, having $1-\beta$ chances in 100 to detect an absolute difference $d$ between these two percentages. The number of replicates (n) could be calculated (Cochran 1977; Dagnelie 1986) using $y$, the number of wilted plus dead seedlings among the 54 seedlings of each unit :

$$
n=\frac{2\left(u_{1-\alpha / 2}+u_{1-\beta}\right)^{2} \sigma^{2}}{d^{2}}
$$

where $n$ is the number of replicates (units), $d$ the absolute difference on $y$ to detect a difference between the two treatments (defined in number of wilted plus dead seedlings ; for example, $d=5.4$ corresponds to an absolute difference of $10 \%$ between the performance of the 2 treatments), $\sigma^{2}$ the variance of $y, \alpha$ and $\beta$ respectively the Type 1 and Type 2 error and $u$ the quantile of the Normal distribution. The variability between units in the tests conducted from 1993 to 1995 on 'Milfeuil' was from 3.92 to 5.32 (standard error of $y$ in Table 4). The number of replicates to use in order to compare two proportions of wilted plus dead seedlings was calculated using the highest standard error of the tests, i.e.

Table 4. Proportions $p$ and standard errors $S E(p)$ of the proportions of dead plus wilted seedlings ; mean number of dead plus wilted seedlings per unit $(\bar{y})$ and standard errors of $y(\sigma)$ in three independent tests

\begin{tabular}{cccccc}
\hline Year & $\begin{array}{c}\text { Number of } \\
\text { units }\end{array}$ & $p$ & $S E(p)$ & $\bar{y}$ & $\sigma$ \\
\hline 1993 & 5 & 0.637 & 0.044 & 36.4 & 5.32 \\
1994 & 6 & 0.688 & 0.030 & 37.2 & 3.92 \\
1995 & 6 & 0.636 & 0.034 & 34.3 & 4.50 \\
\hline
\end{tabular}

Table 5. Number of units (n) to detect $d p$ absolute difference on proportions $p$ or $d y$ absolute difference on dead plus wilted seedling numbers $(y)$, with two first $(\alpha)$ and second $(\beta)$ risk levels

\begin{tabular}{ccccccc}
\hline & \multicolumn{3}{c}{$\alpha=0.05 ; \beta=0.1$} & \multicolumn{3}{c}{$\alpha=0.1 ; \beta=0.2$} \\
\hline$d p$ & 0.10 & 0.20 & 0.30 & 0.10 & 0.20 & 0.30 \\
$d y$ & 5.4 & 10.8 & 16.2 & 5.4 & 10.8 & 16.2 \\
$\mathrm{n}$ & 21 & 6 & 3 & 12 & 3 & 2 \\
\hline
\end{tabular}


$\sigma=5.32$. Results are presented on Table 5 , using for the calculations two first $(\alpha)$ and second type $(\beta)$ errors, and three absolute differences to detect between the two proportions. When the best risk levels are required, we could detect an absolute difference of $10 \%$ between two treatments by using 21 units of 54 seedlings per treatment. This leads to a very powerful design. For instance, in the context of plant breeding i.e. when comparing and screening cultivars for PA resistance, the use of six units per cultivar or treatment could be sufficient to detect differences of 20 or $30 \%$ in cultivar performance. Even more, if the purpose is to detect highly resistant or susceptible cultivars, two units could be sufficient. This validates the use of two replicates per treatment in experiments $1,2,3$. It is obvious that if the variability between units is higher, due to different experimental conditions or device, or to the cultivars, the number of replicates required to detect the same difference or to obtain the same level of precision will have to be increased. On the other hand, the number of replicates has been calculated using units of 54 seedlings. Changing the number of seedlings per unit is equivalent to changing the test and requires to reestablish the number of replicates.

\section{ACKNOWLEDGEMENTS}

The authors are indebted to Dr. R. Michaud for his helpful comments on the manuscript. We wish to thank Laurence Favre and Marilyn Vandier for technical assistance. This programme was partly supported by a grant provided by a plant breeders association : I'ACVF (Association des Créateurs de Variétés Fourragères).

\section{REFERENCES}

Berberet, R.C., J.L. Caddel, and A.A. Zarrabi. 1991. Pea aphid resistance. In Standard tests to characterize alfalfa cultivars. C.C. Fox, R. Berberet, F.A.A. Gray, C.R. Grau, D.L. Jessen, and M.A. Peterson (eds.), North American Alfalfa Improvement Conference, USDA/ARS, Beltsville, MD, I.4.
Bournoville, R. 1976. Enquête sur les insectes nuisibles à la luzerne en production de fourrage Pages 83-86 in: Compte-rendus réunion EUCARPIA, Groupe Medicago sativa, VURV (eds.) Piestany Tchécoslovaquie.

Bournoville, R. 1980. Varietal characteristic under French conditions of some alfalfa cultivars selected for resistance to two insects. EPPO Bull. 10 : 317-322.

Bournoville, R., and B. Comte. 1977. Premiers résultats sur l'étude en France du comportement variétal de la luzerne (Medicago sativa L.) à l'égard du puceron du pois (Acyrthosiphon pisum $\mathrm{H}$.) (Homoptera : Aphididae) et du phytonome (Hypera variabilis H.) (Coleoptera : Curculionidae). Bull. SROP-OILB 3 : 97-101.

Carnahan H.L., R.N. Peaden, F.V. Lieberman, and R.K. Petersen. 1963. Differential reactions of alfalfa varieties and selections to the pea aphid. Crop Sci. $3: 219-222$.

Cochran, W.G. 1977. Sampling techniques, John Wiley and Sons, N.Y., 428 pp.

Dagnelie, P. 1986. Théorie et méthodes statistiques. Les presses agronomiques de Gembloux, Belgique, $463 \mathrm{pp}$.

Ellsbury, M.M., and M.W. Nielson. 1981. Comparative host plant range studies of the blue alfalfa aphid, Acyrthosiphon KondoiShinji, and the pea aphid, Acyrthosiphon pisum (Harris) (Homoptera : Aphididae). Tech. Bull., USDA 1639 : 1-14.

Frazer, B.D. 1972. Population dynamics and recognition of biotypes in the pea aphid (Homoptera : Aphididae). Can. Entomol. 104 : 1729-1733.

Girousse, C., and R. Bournoville. 1994. Biological criteria of the pea aphid Acyrthosiphon pisum Harris and varietal resistance of Alfalfa. Eucarpia/FAO meeting "Management and breeding of perennial lucern for diversified purposes", 4-8 Sept. 1994, Lusignan, France, 251-253.

Hackerott, H.L., E.L. Sorensen, T.L. Harvey, E.E. Ortman, and R.H. Painter. 1963. Reactions of alfalfa varieties to pea aphids in the field and greenhouse. Crop Sci. 3 : 298-301.

Holtkamp, R.H., and A.D. Clift. 1993. Establishment of three species of alfalfa aphids on 24 cultivars of alfalfa. Austr. J. Agric. Res. 44 : 53-58.

Isaak, A., E.L. Sorensen, and E.E. Ortman. 1963. Influence of temperature and humidity on resistance in alfalfa to the spotted alfalfa aphid and pea aphid. J. Econ. Entomol. 56 : 53-57.

Isaak, A., E.L. Sorensen, and R.H. Painter. 1965. Stability of resistance to pea aphid and spotted alfalfa aphid in several alfalfa clones under various temperature regimes. J. Econ. Entomol. 58 : 140-143. 
Kugler, J.L., and R.H. Ratcliffe. 1983. Resistance in alfalfa to a red form of the pea aphid (Homoptera : Aphididae) J. Econ. Entomol. $76: 74-76$.

Nielson, M.W., and W.F. Lehman. 1977. Multiple aphid resistance in CUF 101 alfalfa. J. Econ. Entomol. 70 : 13-14.

Ortman, E.E., E.L. Sorensen, R.H. Painter, T.L. Harvey, and H.L. Hackerott. 1960. Selection and evaluation of pea aphid resistant alfalfa plants. J. Econ. Entomol. $53: 881-887$.

Ridland, P.M., and G.N. Berg. 1981. Seedling resistance to spotted alfalfa aphid of alfalfa and annual medic species in Victoria. Aust. J. Exp. Agric. Anim. Husb. 21 : 59-62.

Schalk, J.M., S.D. Kindler, and G.R. Manglitz. 1969. Temperature and the preference of the spotted alfalfa aphid for resistant and susceptible alfalfa plants. J. Econ. Entomol. 62 : 1000-1003.

Schotzko, D.J, and C.M. Smith. 1991. Effects of preconditioning host plants on population development of russian wheat aphids (Homoptera: Aphididae). J. Econ. Entomol. 84 : 1083-1087.
Smith, O.F., and R.N. Peaden. 1960. A method of testing alfalfa plants for resistance to the pea aphid. Agron. J. 52:609-610.

Smith, C.M., Z.R. Khan, and M.D. Pathak. 1994. Techniques for evaluating insect resistance in crop plants. CRC Press, Boca Raton, Florida, $320 \mathrm{pp}$.

Sorensen, E.L., R.A. Byers, and E.K. Horber. 1988. Breeding for insect resistance. Pages 859-902 in Alfalfa and Alfalfa Improvement, A.A. Hanson et al. (eds)., American Soc. Agronomy, Madison, Wisconsin.

Summers, C.G. 1988. Cultivar and temperature influence on development, survival, and fecundity in four successive generations of Acyrthosiphon kondoi (Homoptera : Aphididae). J. Econ. Entomol. $81: 515-521$. 